\title{
12 \\ Broken promises: women and the 2006 Fiji election
}

\section{Rae Nicholl}

Prior to the 2006 election, the two major political parties specifically promised that there would be an increase in the number of female candidates. Yet, of the 338 candidates they selected, only 27 (8 per cent) were women. ${ }^{1}$ This was a reduction of four compared with the 2001 election - and the same number that stood in 1999 . How could there be so few women candidates when the parties had promised so much?

Promises to women began in 1993, when the Fiji government 'established a policy to increase women's membership of boards, committees and councils by 30 to 50 per cent within the following five years'. ${ }^{2}$ This policy initiative was followed in 1995 by Fiji's ratification of the United Nations Convention on the Elimination of All Forms of Discrimination Against Women (CEDAW). Although countries cannot be forced to comply, article 7 of the convention requires signatory states to take 'all appropriate measures to eliminate discrimination against women in the political and public life of the country'. In particular, CEDAW refers to the right of women to vote and to stand for election; the right to participate in the formulation of government policy; and the right to participate in non-governmental organizations and associations concerned with the public and political life of the country. ${ }^{3}$ The 1997 constitution also contains commitments to women, specifically in the Bill of Rights. The constitution guarantees that 'every person has the right to equality before the law' and that 'a person must not be unfairly discriminated 
against, directly or indirectly, on the ground of his or her actual or supposed personal characteristics or circumstances, including...gender ${ }^{2}{ }^{4}$ It is possible that the weight of expectation - engendered by government promises, CEDAW, and the constitution - led political parties to make some rash promises in the run-up to the 2006 election.

The promises began in September 2004, when the Fiji Labour Party (FLP) announced that it had decided to set aside a significant percentage of seats for women in the 2006 election. A large proportion of these would be safe seats, a party spokesman announced, adding that gender equality was one aspect of the FLP's broader commitment to human rights and social justice. ${ }^{5}$ Eight months later, the National Alliance Party (NAP) announced that it would allocate 50 per cent of its seats to women in the next election. ${ }^{6}$

Hopes rose further when the Minister for Women, Social Welfare and Poverty Alleviation, Adi Asenaca Caucau, informed an International Women's Day celebration on 8 March 2006 that, after giving the subject much thought, she had undergone a 'change of mind'. After years of opposing quotas, she believed now that 'quotas are the way forward, enabling women to become candidates'. She claimed to be in the process of making a submission to cabinet asking for a 30 per cent quota, which would apply to the SDL party only and would contain a sunset clause. There was, she admitted, no strategy for placing women in winnable seats. ${ }^{7}$

Hopes were reinforced on the night before a huge rally in Suva on 17 March 2006, when Prime Minister Qarase told viewers of Fiji One's prime time television news that he was expecting to see a large number of female candidates running for his party, the Soqosoqo Duavata ni Lewenivanua (SDL).

\section{Women MPs}

For women, the results of the election were bitter sweet: bitter, because there had been a reduction in women candidate numbers, but sweet because a total of eight women won seats in the House of Representatives. This was an increase of three women compared with the 2001 election, but the same number as was elected at the 1999 election (Table 12.1).

In the 2006 election, the SDL won 36 seats, five (13.9 per cent) by women. The FLP won 31 seats, two of which went to women (6.5 per cent). The 
UPP won two seats, with one going to a woman (50 per cent). The two new independent members were men.

The SDL consists mainly of indigenous Fijians, is both fiscally and socially conservative, and has close links to the Methodist Church of Fiji. While the party may appear to be an unpromising choice for career-minded women, it has attracted a number of female candidates. Historically, Fiji has had a number of influential women leaders. Importantly, they have - until recently - either been chiefs themselves or have come from chiefly families and enjoyed high status among the indigenous people. Voting for such women is culturally acceptable.

On the other hand, the FLP, which has a large Fiji Indian membership, does poorly in attracting women candidates. This is despite the party having had a woman president, Jokapeci Koroi, since 1991..$^{8}$ (Following the 2006 election, Koroi was nominated by the Leader of the Opposition to the Senate. She had previously served as a Senator and vice-president of the Senate during the period 1999-2000 when the FLP was in power.) Koroi is one of the FLP's Fijian members and, in general, women in the Fijian community are more likely to rise to prominence in their own right than women from the Fiji Indian community. ${ }^{9}$ According to Chandra Reddy, Fiji Indian women remain in a subordinate position because they live within a culture that 'condemns women's assertiveness as disrespectful to those with traditional power' ${ }^{10}$ Such cultural norms may well inhibit women from seeking candidacies, but the paucity of female representatives in the FLP remains disappointing given the promises that the party had made to women in 2004.

The MPs forming the smallest party in the House were those elected to 'General' electorates, seats set aside for representatives of citizens who do not

Table 12.1 Fiji general elections: women candidates and members of parliament, 1999-2006

\begin{tabular}{lcccc}
\hline Year of election & $\begin{array}{c}\text { Total number } \\
\text { of seats }\end{array}$ & $\begin{array}{c}\text { Number female } \\
\text { candidates }\end{array}$ & $\begin{array}{c}\text { Number women } \\
\text { elected }\end{array}$ & $\begin{array}{c}\text { Percentage women } \\
\text { elected to parliament }\end{array}$ \\
1999 & 71 & 27 & 8 & 11.27 \\
2001 & 71 & 31 & 5 & 7.04 \\
2006 & 71 & 27 & 8 & 11.27 \\
\hline
\end{tabular}


belong to the other ethnic groups (Fijian, Indian and Rotuman). In the 2006 election, the UPP attained the feminist goal of achieving equality between the sexes. While it is acknowledged that the party has only two members, one female and one male, from a symbolic viewpoint, attaining parity is a significant achievement.

Of the eight women elected, four were returning incumbents and four were new MPs. The four incumbents - Ro Teimumu Kepa, Adi Asenaca Caucau, Nanise Nagusuca and Losena Salabula - had been ministers or assistant ministers in the previous SDL administration and went into the campaign with the advantage of name recognition in the electorate.

Not all four new members were well known nationally, although two of the women were household names. Known throughout Fiji as the 'Hot Bread Queen', the new SDL member, Mere Samisoni, was contesting for the third time. She is a successful businesswoman - and founding owner of The Hot Bread Kitchen chain of bakeries. Bernadette Rounds Ganilau, the new MP for the UPP, had already achieved a high level of visibility through her broadcasting and other media work and her 'larger-than-life' personality. The other two new members represented the FLP. Adi Sivia Qoro was a former diplomat and women's development adviser at the Secretariat of the Pacific Community, and Monika Raghwan, who is considerably younger than the other women MPs, was an executive officer in a family business, Raghwan Construction, one of the largest construction companies in Fiji.

Two women did not return to parliament after the election. Marieta Rigamoto, the independent member for Rotuma, who had been the Minister for Information, Communications and Media Relations, retired from politics. Ofa Swann (Duncan), who had previously been a member of the New Labour Unity Party, chose to run as an independent, and lost her seat.

\section{Cabinet appointments}

By 24 May, the Prime Minister had selected his new cabinet. Ro Teimumu Kepa was reappointed Minister for Education, Youth and Sports, and the FLP's new MP, Adi Sivia Qoro, was elevated to cabinet to become the Minister for Commerce and Industry. In addition, the Prime Minister brought into cabinet a newly appointed woman senator, Adi Samanunu Cakobau, as Minister 
Without Portfolio in the Prime Minister's Office. In a controversial move, a man, George Shiu Raj, was appointed the new Minister for Women, Social Welfare and Poverty Alleviation.

In a new departure, the Prime Minister also named a number of state ministers, including Adi Asenaca Caucau, who lost her position as Minister for Women, Social Welfare and Poverty Alleviation, and Losena Salabula. Adi Asenaca Caucau took on the position of Minister of State for Housing, while Losena Salabula, who had been an assistant minister in the previous administration, returned to a similar position as Minister of State for the Office of the Prime Minister. Nanise Nagusuca, who had been Assistant Minister, Culture and Heritage, was dropped from cabinet. Finally, subsequent to the UPP becoming the official opposition, Bernadette Rounds Ganilau became Deputy Leader of the Opposition.

\section{The Senate}

The term of the Senate, Fiji's non-elected second chamber, is the same as that of the House of Representatives and, as a consequence, new appointments are made after a general election. Six women (18.8 per cent) have been appointed to the Senate: Adi Samanunu Cakobau and Adi Lagamu Vuiyasawa (Prime Minister's nominees); Adi Koila Nailatikau and Adi Laufitu Malani (Great Council of Chiefs' nominees); and Jokapeci Koroi and Lavinia Padarath (Leader of the Opposition's nominees). As four women (12.5 per cent) of the 32 senators were appointed during the term of the 2001-2006 government, it is encouraging to see the increase in female presence in the Senate in the current government.

\section{Party manifestos}

While party leaders made rash promises to women in public forums, the policies relating to female representation, as set out in their manifestos, were more implicit than explicit. The first manifesto to be released came from the SDL, which held a huge rally in Suva on 17 March 2006 designed to showcase both the manifesto and the party's candidates. The glossy booklet, published in both Fijian and English, contained a section on women along with a raft of other policies. The manifesto told women that they were 'the pillars of 
the nation' and 'the backbone of our families' and that 'the government has always stressed the important part women play in the development of Fiji'. While acknowledging that 'more effort is required to increase the number of women MPs', the manifesto made no suggestions as to how this goal would be achieved. ${ }^{11}$

The FLP's manifesto conveyed similar sentiments regarding women's representation. It stressed that 'women are equal partners with men, and should play a full and active role in the political, economic, cultural and social life of Fiji'. Further, the party noted that 'there are still many barriers to women's full participation' and that women are 'not adequately represented in Parliament' although, as with the SDL, the party provided no initiatives as to how the problem of equitable female representation could be resolved. ${ }^{12}$ The UPP gave no commitment to a quota system but indicated that it would include women parliamentarians in cabinet and the Senate and on select committees. ${ }^{13}$

The two largest losing parties also carried policies for women in their manifestos. As it had promised in May 2005, the NAP proved to be the only major political entity suggesting a quota for women candidates - but with a slight twist. It appeared to be encouraging other political parties 'to adopt a 50 per cent target for women candidates as part of their manifestos' but without committing themselves to a similar policy, although the party did promise to 'create an enabling environment for women, including young women, to seek and advance political careers' ${ }^{14}$ In this respect, the NAP policy had a resonance with the policy proposals not realized in the SDL manifesto, but mooted by the Minister for Women, Social Welfare and Poverty Alleviation, Adi Asenaca Caucau, when she had stressed the desirability of 'creating an enabling environment for women'. ${ }^{15}$ The other big loser in the election, the National Federation Party, also promised to 'increase representation of women in Parliament and other private and public sector boards and institutions', but failed to give any indication of how this promise was to be effected. ${ }^{16}$

\section{Women as voters}

Election observers, especially those from Europe, were concerned about the heavy daily workload of women in Fiji, especially of those living a subsistence lifestyle in the rural areas and outer islands, where there is often no electricity 
or running water. They saw women, many of whom were elderly, with their backs bent double under huge loads of firewood, trudging along dusty roads. When the observers came into the villages, they found that it was the women who had set out fishing at midnight, who had cooked meals for all the visiting election officials, and who had then cleaned up afterwards before returning to their homes to carry on with their own household duties. ${ }^{17}$

These same village women, including many of the very elderly, voted in what appeared to be large numbers, but some were illiterate and needed assistance with filling out their ballot papers. ${ }^{18}$ While observers could not see or hear if these women were being told how to vote by election officials, media reports suggested that family members, in particular, were grooming them to vote in a certain way. Journalist Verenaisi Raicola supported this suggestion in an article published in The Fiji Times on 9 May, which was part way through election week. Entitled 'Elderly unable to cast vote', Verenaisi Raicola told the story of a blind and deaf 83-year-old woman, Seni, from the remote island of Qoma in Tailevu. According to the reporter:

Seini said her son had instructed her how to tick the Dove symbol above the line and that she knew that much was right because she had been reminded over and over again. ${ }^{19}$

The symbol of the dove represented the SDL party. A day after the story appeared in The Fiji Times, Shamima Ali, Executive Director of the Fiji Women's Crisis Centre, told the media that she had received complaints that women in rural areas were being pressured by their husbands and community leaders to vote in a certain manner. ${ }^{20}$

In anticipation of the 'grooming' problem, four of Fiji's women's organizations - fem'LINKpacific, Fiji Women's Rights Movement, Fiji Women's Crisis Centre and Women's Action for Change - combined to place full-page advertisements in the daily newspapers on at least two occasions during the voting period. Titled 'No-one sees who you vote for. No-one will ever know', the advertisement encouraged women to read the party manifestos; to remember what had been said in the campaigns; and to ask what politicians had done for the community. The advertisement ended by reminding women that 'this is your choice, your vote - yours alone' ${ }^{21}$

Although it could be argued that the placement of the advertisements was mis-timed, to this reader it seemed clear that they were designed to alleviate 
the pressure to vote in a certain way that some women might be placed under by family members. However, the reaction to the advertisements by the Supervisor of Elections, Semesa Karavaki, was one of displeasure. According to Pacific Media Watch, the Supervisor confirmed that there would be a police investigation into what he described as 'the breach of Fiji's electoral laws that ban electioneering once polling has begun'. ${ }^{22}$ At the time of writing, no police action against the women's organizations had begun.

As well as being voters, women played other roles in the election. The election cycle began with the registration of voters, a process carried out all over the country by teams of enumerators, people who travelled the length and breadth of Fiji to make sure every eligible citizen's name appeared on the electoral roll. Enumerators were expected to travel by foot and walk house-tohouse, often over rough and mountainous terrain. In some cases, they were required to travel overnight and sleep in villages. Because of racial sensitivities, one problem that arose during the voter registration process was the suggestion that more Fijians than Fiji Indians were taking on the enumerator role. Some members of the Fiji Indian population were suspicious of Fijian enumerators who came to their houses and felt that their enrolment details might not be treated with sufficient diligence. Another concern was the shortage of female Fiji Indian enumerators, especially in rural areas where some older Fiji Indian women were reluctant to give their personal details to men. According to the Returning Officer, Northern Division, acquiring a racial - and gender - balance of enumerators was desirable, but it had proved difficult to maintain, and the necessity for enumerators to occasionally sleep away from home may have been a factor in the low recruitment of Fiji Indian women. ${ }^{23}$

Besides being employed as enumerators, many women worked during election week as polling clerks, joining teams of up to 18 members (including two police officers). The teams were all of mixed gender, but, on the whole, the polling clerks were women and the presiding officers were men, although there was a handful of women who took on the senior roles in the polling stations and vote counting centres. Many women voters, especially those with literacy or health problems, reported feeling more confident and comfortable if a woman assisted them. Providing more senior women in leadership roles at election time would be another step towards making the electoral process more female-friendly. 


\section{Action to increase women's participation and representation}

The women's movement in Fiji has worked for decades to improve the profile of women in public life, and its various organizations have produced numerous documents and reports on the issue. ${ }^{24}$ These publications have highlighted the many barriers to women's advancement, but, as yet, there have been no incremental increases in the number of women elected to the Fiji Parliament since eight women were elected in 1999. While disheartening, this stasis has not stopped women's organizations from taking action to improve the situation.

As previously discussed, four organizations jointly took out advertisements in the daily papers, reminding women that their vote was secret and that no one needed to know how they had cast their ballot. In addition to assisting with the advertisements, the fem'LINKpacific women's media organization broadcast interviews with women candidates and covered issues concerning the election.

One of the well-documented barriers preventing women from campaigning effectively is the lack of campaign finance. ${ }^{25}$ The cost of running an effective campaign in Fiji can be considerable. Ofa Swann (Duncan) spent two terms in the House of Representatives (1999 and 2001) and was contesting her third election in 2006 as an independent candidate. She claimed that the estimated cost of her campaign was F $\$ 25,000$ and that her main methods of fundraising would be hosting private parties and selling clothes. ${ }^{26}$

Political parties in many countries usually contribute a small amount to individual campaigns, sometimes through the production of advertisements featuring the party leader with the candidate, but large costs often remain to be absorbed by candidates. Women, generally, do not have the capacity to generate large sums of money, especially not in Fiji where wages and salaries are low. As well, women often are in no position to take out loans or mortgages. Feminists have understood this problem and, in some countries, financial assistance for women may come from organizations such as EMILY's list in the United States, which raises money for candidates who are members of the Democratic Party. ${ }^{27}$

In an effort to assist women candidates in Fiji with their heavy financial obligations, the Fiji Women's Rights Movement launched the Women In Politics (WIP) Appeal by donating F\$1,000 to start the fundraising campaign. The 
appeal was designed to assist female candidates, irrespective of their political affiliation, and to mobilize women voters. ${ }^{28}$ While the time frame for the appeal was short, it was successful, and, on the first day of election week, the Fiji Women's Rights Movement placed an advertisement in the press thanking all donors to the WIP Appeal and affirming that their 'generous donation was shared equally amongst all women candidates in the 2006 elections, irrespective of their political party affiliations'. ${ }^{29}$ The movement also produced a leaflet that was inserted into the daily newspapers entitled 'Women Ask', which identified the 'strengths and strategies proposed by political parties to address the concerns of women' ${ }^{30}$

\section{Recruiting female candidates}

One reason why political parties fail in their promises to field more female candidates is the shortage of willing and credible women. Unfortunately, attracting female candidates is problematic worldwide as capable women are not always interested in the prospect of a political career. ${ }^{31}$ Women in Fiji are no different. Adi Asenaca Caucau noted that the SDL has as much trouble as any other party in attracting credible candidates even though there is strong grass roots support in the party'. In the bid to find candidates, the SDL had 'not only approached chiefly women, but other women as well. ${ }^{32}$

If political parties really want to appear sympathetic to gender equality, they need to actively seek more women candidates and to allocate them safe seats, where they have a good chance of winning. Once women are selected, parties must acknowledge the barriers that they face. In particular, they must help women candidates raise the funds to cover the costs of campaigning.

\section{The alternative vote and a quota system}

Fiji uses the alternative vote electoral system to elect its members of parliament. Imported from Australia, the alternative vote replaced the first-past-the-post voting system and has been used since the 1999 election. The alternative vote is a majoritarian system very similar to first-past-the-post in that both systems are based on single-member electorates; the principal difference is that the alternative vote gives electors the choice of ranking candidates in order of preference. In any system with single-member electorates, there is a strong 
tendency to choose 'safe' candidates, who will not offend any citizens within the voting community. The result of this selection process tends to be a dull uniformity of middle-aged middle-class male candidates across all parties. The system does not assist those groups in society, such as women and ethnic minorities, who traditionally have been under-represented in parliament. ${ }^{33}$

The quickest way to bring diversity to parliament would be to abolish the alternative vote with its concomitant multiple communal rolls and introduce a proportional representation system, either the Mixed-Member Proportional system used in New Zealand or the list system used in South Africa. Both these voting systems have been successful in bringing a critical mass of women (usually considered to be 30 per cent) into parliament. For instance, in 2004, women won 32.8 per cent of the seats in South Africa's lower house, the National Assembly. In the following year, New Zealand women won 32.2 per cent of the seats in that country's House of Representatives. ${ }^{34} \mathrm{~A}$ critical mass is considered important because there is an assumption, supported by the United Nations, that the greater the number of women in a legislature the more seriously women's social, economic, legal and cultural needs will be taken. ${ }^{35}$

One alternative to changing the electoral system could be the introduction of a quota system. Political parties need to be encouraged to consider this option seriously, to look at overseas models, and to consider ways in which they could institute a quota within their organizations. For example, South Africa's ruling party, the African National Congress, has enshrined a 30 per cent quota for women within its constitution. ${ }^{36}$

Another form of quota could be the use of reserved seats for women. Fijian constitutional lawyers could look at the New Zealand example of reserved seats for Maori, although the difficulty of introducing a new system that asked citizens to complete accurately a third ballot paper (there is already one ballot paper for the communal roll and another for the general roll) might prove a disincentive in pursuing this idea.

\section{Conclusion}

Attitudinal changes will be needed if women in Fiji are to forge ahead into leadership roles. Conservative views about women remain strong, as was evidenced by a recent letter to the editor in The Fiji Times. Under the heading 
'Good leaders', the correspondent stated that: 'it is imperative to mention that we prefer a male president of Fiji. Women should be barred from holding the post ${ }^{37}$ While feminists may not have been too surprised by the correspondent's misogynistic tendencies, they were dismayed and disappointed when the Assistant Minister for Culture and Heritage, Nanise Nagusuca, made several public statements that appeared to criticize the work of women's organizations. In one statement, she said:

The traditional Fijian set-up does not make mention of the woman being superior or even on equal standing with men. A lot of Fijian women know that they should be subservient to their husbands and be good mothers to their children. They should see that the home is well looked after and that the life of the family members is comfortable. Women's rights is a western concept and shouldn't be adopted. ${ }^{38}$

The stagnation in women's political advancement in Fiji was apparent in the 2006 election. While the situation had improved over the 2001 result, women have yet to build on their 1999 success, when eight women were elected to parliament. Unless MPs and political parties decide on a critical review of the voting system and the consequent changes required to the constitution, or seriously consider introducing a quota system, women have little hope of increasing their parliamentary presence. If changes are not made, promises of increased representation for women will continue to be empty rhetoric and to be broken.

\section{Notes}

1 Fiji Elections Office, <http://www.elections.gov.fj> (accessed 10 May 2006).

2 Huffer, E. 'Review of Institutional Mechanisms, Policies, Legislation and Programmes in Support and Promotion of Gender Equality in the Republic of the Marshall Islands, Samoa and Fiji', Pacific Women's Bureau, Ninth Triennial Conference of Pacific Women, Nadi, Fiji, 2004, p.43.

3 The Pacific Regional Human Rights Education Team. CEDAW: the Convention on the Elimination of all forms of Discrimination Against Women, Suva, 2001. Fiji ratified CEDAW on 27 August 1995.

4 Section 38, (1) and (2) (a), Constitution of the Republic of the Fiji Islands, 27 July 1998, p.26.

5 Fiji Sun, 21 September 2004, p.5.

6 Fiji Sun, 6 May 2005, p.1.

7 Speech given to the International Labour Organisation, Suva, 8 March 2006.

8 Jokapeci Koroi, Remarks made to the Women and Leadership: 6th Triennial Conference 
Report, The Fiji Association of Women Graduates, Parliament of Fiji Complex, Suva, 6 \& 7 May 2000, p.20.

9 United States Department of State, Fiji: Country Reports on Human Rights Practices 1999. Released by the Bureau of Democracy, Human Rights and Labor, <http://www.state. gov/g/drl/rls/hrrpt/1999/287.htm> (accessed 26 July 2006).

10 Reddy, C. 2000. 'Women and politics in Fiji', in B.V. Lal (ed.) Fiji Before the Storm: Elections and the Politics of Development, Asia Pacific Press, The Australian National University, Canberra, pp.149-60.

11 Soqosoqo Duavata ni Lewenivanua, 2006. Beat Poverty. Raise prosperity. 2006 SDL Manifesto, Soqosoqo Duavata ni Lewenivanua, Suva, p.24.

12 Fiji Labour Party, Change the Future. Vote Labour. 2006 Election Manifesto, Fiji Labour Party, 2006, p.24.

13 Fiji Women's Rights Movement, Women Ask - summary of a pre-election survey of all parties' policies on concerns of women, Fiji Women's Rights Movement, Suva, May 2006.

14 National Alliance Party of Fiji, Manifesto - 2006, National Alliance Party of Fiji, 2006, p.38.

15 Speech given to the International Labour Organisation, Suva, 8 March 2006.

16 National Federation Party, 2006 General Elections Manifesto - United Fiji, National Federation Party, Samabula, 2006, p.16.

17 Personal discussions with election observers from the European Union, Commonwealth and the Pacific Forum, Labasa, May 2006.

18 Chandra, D. \& Lewai, V. 2005. Women and Men of Fiji Islands: Gender Statistics and Trends, Population Studies Programme, University of the South Pacific, Suva, p.18. Statistics show that older rural women have the lowest levels of literacy, with Fiji Indian women being the worst affected.

19 Raicola, V. 'Elderly unable to cast vote', The Fiji Times, 9 May 2006, p.7.

20 Fiji Gold FM, Report on comments made by Shamima Ali of the Fiji Women's Crisis Centre, 10 May 2006.

21 'Fem'LINKpacific, Fiji Women's Rights Movement, Fiji Women's Crisis Centre, and Women's Action for Change', The Fiji Times, 6 May 2006, p.73 and Fiji Sun, 10 May 2006, p.13.

22 Pacific Media Watch, 'Women activists cited over electoral adverts', <http://www.pmw.c2o. org>, 10 May 2006.

23 Interview with Officer in Charge of Postal Ballots - Northern Division, Labasa, 11 May 2006.

24 Pacific Regional YWCA. 2000. Pacific Regional Report on the Implementation of the Beijing Platform for Action, Suva, Fiji; Fiji Women's Rights Movement. 2002. Exploring Women's Employment Rights, Suva, Fiji,; Fiji Association of Women Graduates. 2003. Humanising Globalisation: The Challenges for Pacific Women, 7th Triennial Conference Report, Pacific Harbour International Hotel, Deuba, Fiji Islands; Schoeffel, P. 2004. 'Pacific Platform for Action on Women: An Evaluation of the Thirteen Critical Issues and the Status of Pacific Women: 1994-2004', Pacific Women's Bureau, Ninth Triennial Conference of Pacific Women, Nadi, Fiji; Pacific Regional Office of UNIFEM, 2005. Developing a More Facilitating Environment for Women's Political Participation in Fiji, Suva, Fiji.

25 Carroll, S.J. 1994. Women as Candidates in American Politics, second edition, Indiana University Press, Bloomington, pp.49-51; Darcy, R., Welch, S. \& Clark, J. 1994. Women, 
Elections and Representation, second edition, revised, University of Nebraska Press, Lincoln, pp.71-73; Norris, P. \& Lovenduski, J. 1995. Political Recruitment: Gender, Race and Class in the British Parliament, Cambridge University Press, Cambridge, pp.146-47. Rina, S. 'Swann ready for her fight', Fiji Sun, 25 March 2006, p.2. EMILY's list is an acronym for Early Money Is Like Yeast.

Virisila Buadromo, 'FWRM Kick Starts WIP Appeal', media release, Fiji Women's Rights Movement, 6 April 2006.

29 Fiji Women's Rights Movement, 'WIP Appeal - Funding Progress', The Fiji Times, 6 May 2006, p.44.

30 Fiji Women's Rights Movement, 'Women Ask', election pamphlet, May 2006.

Nicholl, R. 2001. The Woman Factor: Candidate Selection in the 1990s - New Zealand, Guam and South Africa, unpublished PhD thesis, Victoria University of Wellington, New Zealand. Speech given to the International Labour Organisation, Suva, 8 March 2006. Nicholl, R. 2006. 'Electing women to parliament: Fiji and the alternative vote electoral system, Pacific Journalism Review, 12(1):87-107. Inter-Parliamentary Union, Geneva, <http://ipu.org/wnm-e/classif.htm> (accessed 20 May 2006).

35 United Nations Office at Vienna. 1992. Women in Politics and Decision-Making in the Late Twentieth Century, Martinus Nijhoff Publishers, Netherlands, p.107.

36 Constitution of the African National Congress as amended by and adopted by the 51st National Conference, December 2002. <http://www.anc.org.za/ancdocs/history/const/ const2002.html> (accessed 23 June 2006). The Fiji Times, 17 March 2006, p. 6. Up Close and Personal Column, Daily Post, 29 April 2006. Nanise Nagusuca made similar remarks in a press statement released by the Ministry of Information on 6 December 2005 (Press release no 1614/10). 